\title{
Masked millennial-scale climate variations in South West Africa during the last glaciation
}

\author{
I. Hessler, L. Dupont, D. Handiani, A. Paul, U. Merkel, and G. Wefer \\ MARUM - Center for Marine Environmental Sciences, University of Bremen, Bremen, Germany \\ Correspondence to: I. Hessler (ihessler@marum.de)
}

Received: 30 September 2011 - Published in Clim. Past Discuss.: 20 October 2011

Revised: 14 February 2012 - Accepted: 2 April 2012 - Published: 24 April 2012

\begin{abstract}
To address the connection between tropical African vegetation development and high-latitude climate change we present a high-resolution pollen record from ODP Site 1078 (off Angola) covering the period 50-10 ka BP. Although several tropical African vegetation and climate reconstructions indicate an impact of Heinrich Stadials (HSs) in Southern Hemisphere Africa, our vegetation record shows no response. Model simulations conducted with an Earth System Model of Intermediate Complexity including a dynamical vegetation component provide one possible explanation. Because both precipitation and evaporation increased during HSs and their effects nearly cancelled each other, there was a negligible change in moisture supply. Consequently, the resulting climatic response to HSs might have been too weak to noticeably affect the vegetation composition in the study area. Our results also show that the response to HSs in southern tropical Africa neither equals nor mirrors the response to abrupt climate change in northern Africa.
\end{abstract}

\section{Introduction}

The last glacial period (73.5-14.7 ka BP; Sanchez Goñi and Harrison, 2010) including the deglaciation (in this study considered as $14.7-10 \mathrm{ka} \mathrm{BP}$ ) is characterised by abrupt climate perturbations on millennial and centennial time scales. Millennial-scale climate changes associated with Northern Hemisphere Heinrich Stadials (HSs) are thought to be transmitted by both the atmospheric and oceanic circulation, resulting in a near-global footprint (e.g. Alley et al., 1999; Hostetler et al., 1999; Broecker, 1996). Heinrich events are defined by the occurrence of layers of ice-rafted debris in the North Atlantic (Heinrich, 1988). However, HSs are related to an abrupt cooling of the North Atlantic region due to a reduction or possibly even a shut-down of the Atlantic Meridional Overturning Circulation (AMOC) (e.g. Broecker, 1994). Hence, an HS contains a Heinrich event but is not equivalent to it (Barker et al., 2009).

Ice core records from Greenland and Antarctica reveal a contrasting temperature response during HSs, namely cooling in the Northern and warming in the Southern Hemisphere (EPICA members, 2006). This anti-phase behaviour is suggested to result from the reduced strength of the AMOC. As a consequence, the temperature decreases in the North and heat accumulates in the South, which represents the concept of the bipolar see-saw (Broecker, 1998; EPICA members, 2006; Barker et al., 2009).

In the tropics, it is presumed that a southward shift in the migration pattern of the Intertropical Convergence Zone (ITCZ) is a persistent feature related to the slowdown of the AMOC (Mulitza et al., 2008; Lee et al., 2011). The southward shift of the ITCZ may also play an important role in the atmospheric transmission of the Northern Hemisphere HSs signal (Lee et al., 2011). Model simulations conducted under modern climate boundary conditions indicate that a southward shift of the ITCZ causes precipitation anomalies over tropical South America and tropical Africa (Vellinga and Wood, 2002; Zhang and Delworth, 2005). The precipitation anomalies are reflected in tropical South American vegetation records by an opposing development north and south of the modern position of the ITCZ (Hessler et al., 2010). Drier conditions north of the modern position of the ITCZ led to abruptly expanding salt marsh vegetation (González et al., 2008; González and Dupont, 2009). In contrast, south of it forests expanded due to an increase in moisture availability (Dupont et al., 2010). It is hypothesised 
that in the African tropics, the impact of HSs is similar, with arid conditions prevailing north of the modern position of the ITCZ (e.g. Mulitza et al., 2008) and wetter conditions south of it (Dupont et al., 2008; Collins et al., 2010). Collins et al. (2010), however, suggest that the African rainbelt rather contracts during abrupt climate change, presumably leading to an increase of precipitation in southern equatorial Africa during HSs compared to the Last Glacial Maximum (LGM).

Most studies that deal with abrupt climate variability in the African tropics cover HS1 (e.g. Dupont et al., 2008; Collins et al., 2010; Handiani et al., 2012). During HS1 the environmental background conditions differed substantially from the ones that prevailed during Marine Isotope Stage 3 and its HSs. In addition, the nature of the vegetation response to HSs in tropical Africa varies from site to site, and where multiple HSs are registered at a site, the vegetation changes are not identical (Hessler et al., 2010). In general, atmospheric and oceanic processes controlling the tropical African climate and vegetation composition are highly complex and still only partly understood (Gasse et al., 2008).

We present here a high-resolution pollen record of ODP Site 1078 (off Angola) which reveals the vegetation and climate development of Angola and the southern Congo Basin between 50 and $10 \mathrm{kaBP}$.

To get insight into the atmospheric and oceanographic processes that affect the regional vegetation development during HSs, model simulations have been performed. The combination of data and model experiments is a unique opportunity to evaluate the importance of different forcings on tropical vegetation, particularly during abrupt climate perturbations.

Hessler et al. (2010) showed that the vegetation response in Southern Hemisphere Africa during HSs is marked by an increase in arboreal taxa. Considering the increase in moisture availability in tropical Africa during HS1 (Collins et al., 2010), we would expect an expansion of forest and woodland in Angola and the southern Congo Basin as a response to abrupt climate variations. In this study we want to verify if this expectation is mirrored in our vegetation record. The catchment area of ODP Site 1078 is anticipated to be most sensitive to climate change (Dupont et al., 2008) and has lacked high-quality terrestrial records so far.

\section{Study area}

\subsection{Modern regional climate and oceanic conditions}

The climate of the African tropics is strongly coupled to the latitudinal position of the ITCZ, the trade winds, and the monsoon circulation. Due to the strong linkage between variations in atmospheric and oceanic conditions, the position of the ITCZ follows an annual cycle. During austral winter the ITCZ is in its northernmost position $\left(15-18^{\circ} \mathrm{N}\right)$ and shifts to its southernmost position during austral summer (5$6^{\circ} \mathrm{N}$ in the western part of Africa, $15-20^{\circ} \mathrm{S}$ in the eastern part) (Fig. 1; Gasse et al., 2008). The shift of the ITCZ to its northernmost position also indicates the beginning of the summer monsoon and hence the rainy season (Sultan and Janicot, 2003). The annual migration pattern of the ITCZ affects the rainfall distribution in tropical regions by inducing alternating wet and dry seasons. In addition, the eastward penetrating West African Monsoon and the trade winds control the precipitation by bringing moisture from the Atlantic Ocean into tropical Africa (Gasse et al., 2008; Nicholson, 2000). The inland flow of moisture-laden air-masses is limited by the highlands of East Africa and the surface position of the Congolian Air Boundary, the southern branch of the ITCZ (Leroux, 1983).

The system of ocean currents dominating the South East Atlantic also contributes to the complexity of our research area. The north-westward flowing Benguela Current (BC) separates at around $24^{\circ}-30^{\circ} \mathrm{S}$ into the westward directed Benguela Ocean Current (BOC) and the northward oriented Benguela Coastal Current (BCC) (Stramma and Peterson, 1989; Shannon and Nelson, 1996; Fig. 1). The BC and the coastal upwelling are driven by the South East trade winds. As a result of the convergence of the $\mathrm{BCC}$ with the southward directed Angola Current (AC), the Angola-Benguela Frontal Zone $(\mathrm{ABF})$ emerges, separating the warm $\mathrm{AC}$ waters from the cold Benguela upwelling regime (Fig. 1). Similar to the seasonal shifts of the ITCZ, the ABF reaches its northernmost position in austral winter $\left(20^{\circ} \mathrm{S}\right)$ and is farthest south during austral summer $\left(16^{\circ} \mathrm{S}\right)$ (Shannon et al., 1987).

\subsection{Recent South West African vegetation composition}

Several studies (Hooghiemstra et al., 2006; Dupont, 2011; and references therein) have shown that the distribution of pollen and spores in marine sediments reflects the vegetation composition on the adjacent continent well. Thus, analysing the past pollen composition of marine sediments provides a strong tool to reconstruct the vegetation and climate history of the continent.

The close proximity of ODP Site 1078 to the African continent implies a pollen source area that covers several vegetation zones (Fig. 1). According to the trajectory model of Dupont and Wyputta (2003), the pollen source area for ODP Site 1078 is Angola and the southern Congo Basin. The prevailing wind pattern during austral spring may also cause the transport of terrestrial particles from the northern Namib Desert into the Angola Basin. Dupont and Wyputta (2003) indicate that the pollen source area has been stable over the investigated time-frame of $50-10 \mathrm{ka} \mathrm{BP}$ and that a potential dispersal of pollen and spores by ocean currents is minor. Fluvial transport is also important since ODP Site 1078 is located off the mouth of the Balombo River, which traverses several vegetation zones.

Simplifying the South West African vegetation pattern according to White (1983), eight vegetation types can be distinguished (Fig. 1). In the north of the pollen source area, 


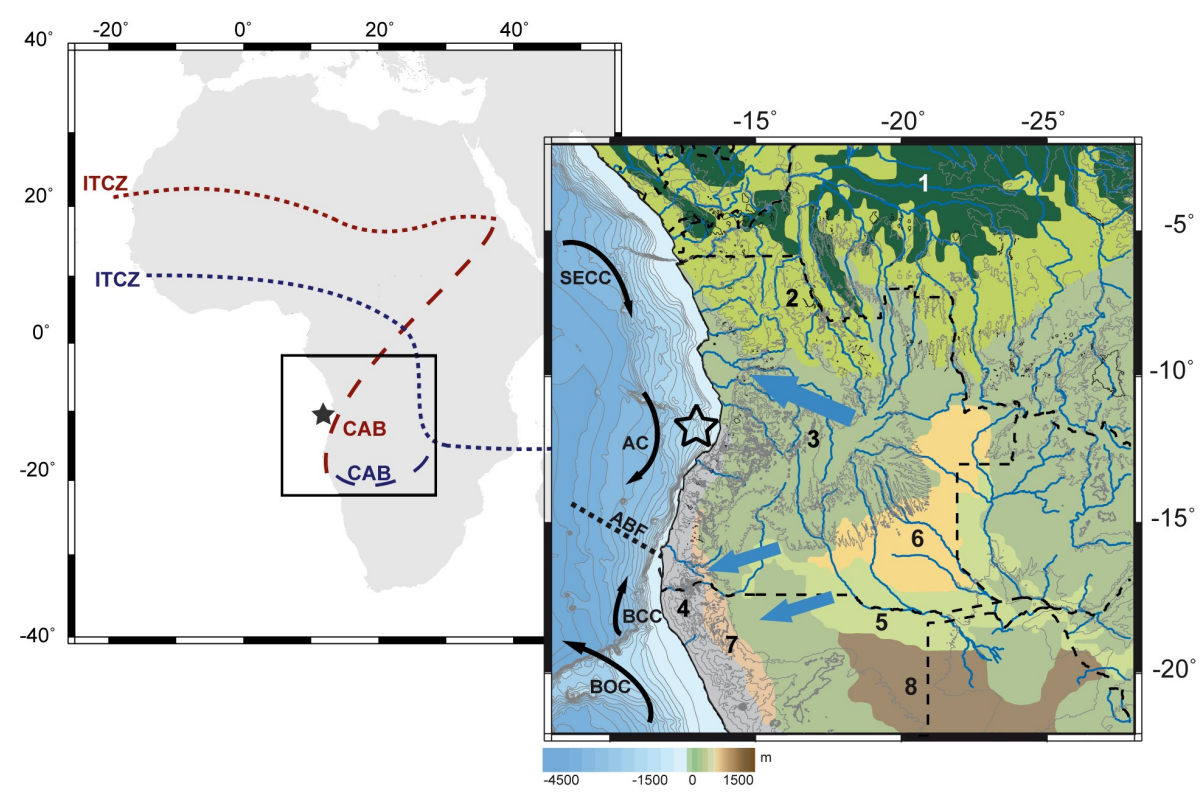

Fig. 1. On the left the position of the Intertropical Convergence Zone (ITCZ) and Congolian Air Boundary (CAB) is indicated for austral summer (red) and austral winter (blue). The black square shows the extent of the figure on the right hand side. The location of ODP Site 1078 is indicated by a star. In the right-hand figure, the prevailing vegetation types in the pollen source area of ODP Site 1078 are simplified after White (1983) and modern South East Atlantic bathymetry and surface water oceanography are shown. $1=$ Tropical forest of the Guineo-Congolian phytogeographical region; $2=$ transition between tropical forest and dry forest/savannah; $3=$ dry forest/savannah of the Zambezian phytogeographical region, wetter Miombo woodland above $1000 \mathrm{~m}$ altitude, Podocarpus above $1500 \mathrm{~m}$ altitude; $4=$ desert and semi-desert of the Nama-Karoo phytogeographical region; $5=$ deciduous forest; $6=$ grassland and Miombo woodland; $7=$ woody shrubland; $8=$ dry deciduous forest and savannah of the Kalahari. Blue lines indicate major rivers. Blue arrows indicate major wind transport direction of the pollen towards the core location (Dupont and Wyputta, 2003). AC = Angola Current; ABF = Angola-Benguela Front; BCC = Benguela Coastal Current; BOC = Benguela Ocean Current; BC=Benguela Current. Star indicates location of ODP Site 1078.

tropical forest of the Guineo-Congolian phytogeographical region prevails. To the south a transition zone between tropical forest and dry forest/savannah vegetation occurs. Wide parts of Angola are occupied by vegetation of the Zambezian region, which is characterised by a diverse flora ranging from closed, semi-deciduous forests in the North to broad-leaved, savannah types in the South. On the nutrient-poor soils of the Angolan highlands (above $\sim 1000 \mathrm{~m}$ altitude), Miombo woodland, a distinctive type of savannah woodland dominated by Brachystegia trees, is widespread. Afromontane forests including the conifer tree Podocarpus exist in only a few high mountain sites in Angola (above $\sim 1500 \mathrm{~m}$ altitude). The semi-desert vegetation of the southern Angolan coastal areas belongs to the Nama-Karoo phytogeographical region and is characterised by small shrubs and succulents. The semi-desert vegetation in coastal Angola is influenced by the offshore oceanic circulation. Particularly the cold BCC and the related upwelling area reduces atmospheric convection and minimises precipitation (Nicholson and Entekhabi, 1987). Dry deciduous forest and savannah vegetation dominate the pollen source area in the South East.

\section{Material and methods}

\subsection{Site description and age model}

The analysed sediments originate from ODP Site 1078 Hole $\mathrm{C}$ that is located in the Bight of Angola $\left(11^{\circ} 55^{\prime} \mathrm{S}\right.$, $13^{\circ} 24^{\prime} \mathrm{E}$ ) in $426 \mathrm{~m}$ water depth (Fig. 1). Lithologically, the material is composed of moderately bioturbated, olive-grey and dark olive-grey silty clay with varying amounts of nannofossils and foraminifera (Wefer et al., 1998).

The chronostratigraphy used in this study was established by linear interpolation of accelerator mass spectrometry (AMS) radiocarbon dates that have been determined on planktonic foraminiferal tests and molluscs fragments (Kim et al., 2003; Rühlemann et al., 2004; Dupont et al., 2008). More specifically, planktonic foraminifera samples used for AMS dating were a mixture of Globigerinoides ruber, Globogerinoides sacculifer, Orbulina universa, Neogloboquadrina dutertrei, and Globorotalia menardii. The dated mollusc for the age control point 10281 cal yr BP (Lab. no. KIA13017) (Kim et al., 2003; Rühlemann et al., 2004) has been precisely identified as Nacariua wolfi. Further age control points based on molluscs 
(Kim et al., 2003; Rühlemann et al., 2004) have been measured on unidentified fractured specimens.

Fourteen radiocarbon dates are within the investigated time interval of 50-10 ka BP and have been calibrated using INTCAL98 (Stuiver et al., 1998), MARINE04 (Hughen et al., 2004) and Fairbanks0107 (Fairbanks et al., 2005). The radiocarbon dates were corrected with a reservoir age of $400 \mathrm{yr}$ reflecting the present-day global average (Hughen et al., 2004). Although simulations for the glacial ocean indicate an increase in the oceanic reservoir age of up to $600 \mathrm{yr}$ (Butzin et al., 2005), additional $200 \mathrm{yr}$ in the glacial dates of ODP Site 1078 would not significantly alter the age model (Dupont et al., 2008) and the interpretation of our vegetation record. Model simulations also show that temporal fluctuations in the marine reservoir age are of minor importance in the tropical Atlantic (Hughen et al., 2004; Franke et al., 2008). All ages given here are in $1000 \mathrm{yr}$ calibrated before present (ka cal BP).

\subsection{Analytical methods}

For pollen analysis, samples were taken every 2 to $7 \mathrm{~cm}$, resulting in an average temporal resolution of about $300 \mathrm{yr}$. All samples were prepared using standard palynological procedures (Faegri and Iversen, 1989), which includes decalcification with diluted $\mathrm{HCl}(\sim 10 \%)$ and the removal of silicates with HF $(\sim 40 \%)$. During decalcification, two Lycopodium clavatum tablets were added to determine the pollen concentrations (pollen grain $/ \mathrm{cm}^{3}$ ) (Stockmarr, 1971). To remove particles with a diameter $<10 \mu \mathrm{m}$ the samples were sieved over a $8 \mu \mathrm{m}$ mesh using ultrasonic treatment. For identification of pollen grains, spores and other palynomorphs, the samples were mounted in glycerine and microscopically examined at a magnification of 400 and 1000 times. About 300 grains of pollen and spores were counted for each sample. Only in a few samples, only 100-250 grains were counted due to a low pollen concentration in the sediments (Fig. 2a). The different types of pollen, spores and palynomorphs were distinguished using the reference collection of University of Göttingen, Department of Palynology and Climate Dynamics, the African Pollen Database (http://medias.obs-mip.fr/pollen/) as well as several publications (Bonnefille and Riollet, 1980; Maley, 1970; Sowunmi, 1973, 1995; Ybert, 1979). The percentages are calculated on the basis of the pollen sum including terrestrial pollen taxa, aquatics (mainly Cyperaceae and Typha) and spores (mainly ferns). Identified pollen and spores have been summarised into the groups "tropical seasonal forest", "mountain vegetation", "Miombo woodland", "dryforest/savannah", and "semi-desert" following the climatic and ecological preferences of the pollen taxa-related plants (see Supplement).

Potential taphonomic biases such as differential preservation of pollen and spores are considered minor for our study site since (1) the high sedimentation rates mostly prevent the palynomorphs from degradation by oxygen and (2) the optical appearance of the pollen and spores gave no indication of degradation or differential preservation.

The statistical precision of the pollen percentages is shown in Fig. 2b. We calculated the upper and lower error for a $95 \%$ confidence interval by considering the proportion of each vegetation group within the pollen sum (Maher, 1972).

\subsection{Models and experiments}

Model experiments have been conducted using the University of Victoria Earth System Climate Model (UVic ESCM version 2.8; Weaver et al., 2001) including dynamic vegetation (TRIFFID; Cox, 2001) and land-surface components (MOSES 2; Cox et al., 1999) (Fig. 3). The UVic ESCM is a Earth System Model of Intermediate Complexity (EMIC, cf. Claussen et al., 2002) and owes its efficiency to a simplified atmospheric component (Weaver et al., 2001). Although this may be a limiting factor, Stouffer et al. (2006) showed convincingly for present day conditions that EMIC results are qualitatively comparable to the results of models that contain an Atmospheric General Circulation Model.

The TRIFFID model simulates the state of the terrestrial biosphere in terms of soil carbon and the structure and coverage of five plant functional types (broadleaf trees, needleleaf trees, $C_{3}$ grasses, $C_{4}$ grasses and shrubs) (Cox, 2001). The land surface scheme MOSES 2 (1) calculates the surface-toatmosphere fluxes of heat and water, (2) updates the surface and subsurface variables that affect these fluxes, and (3) calculates the vegetation-to-atmosphere fluxes of $\mathrm{CO}_{2}$ (Cox et al., 1999). The major vegetation composition has been diagnosed in terms of mega-biomes as classified by the BIOME6000 project (Harrison and Prentice, 2003) and is compared to our palaeovegetation record. A detailed description of the simulation design and boundary conditions is given in Handiani et al. (2012). Simulations for the two time periods of HS1 and the LGM have been accomplished. HS-like climate conditions have been generated by adding fresh-water to the North Atlantic under glacial boundary conditions. All presented model results show the anomalies between the HS1 and LGM simulations.

\section{Results}

\subsection{Pollen data}

The diagram presented in Fig. 2a covers the interval 50$10 \mathrm{cal}$ ka BP. It shows percentages of identified pollen taxa grouped according to the ecological preferences of the associated plants (see Supplement) and the three most common pollen taxa (Podocarpus, Poaceae and Cyperaceae). In addition to the pollen percentages, the concentrations (grains $/ \mathrm{ml}$ ) for the same pollen groups and taxa are indicated in Fig. 2a. Pollen concentrations provide an independent measure for their representation in the sediment. 


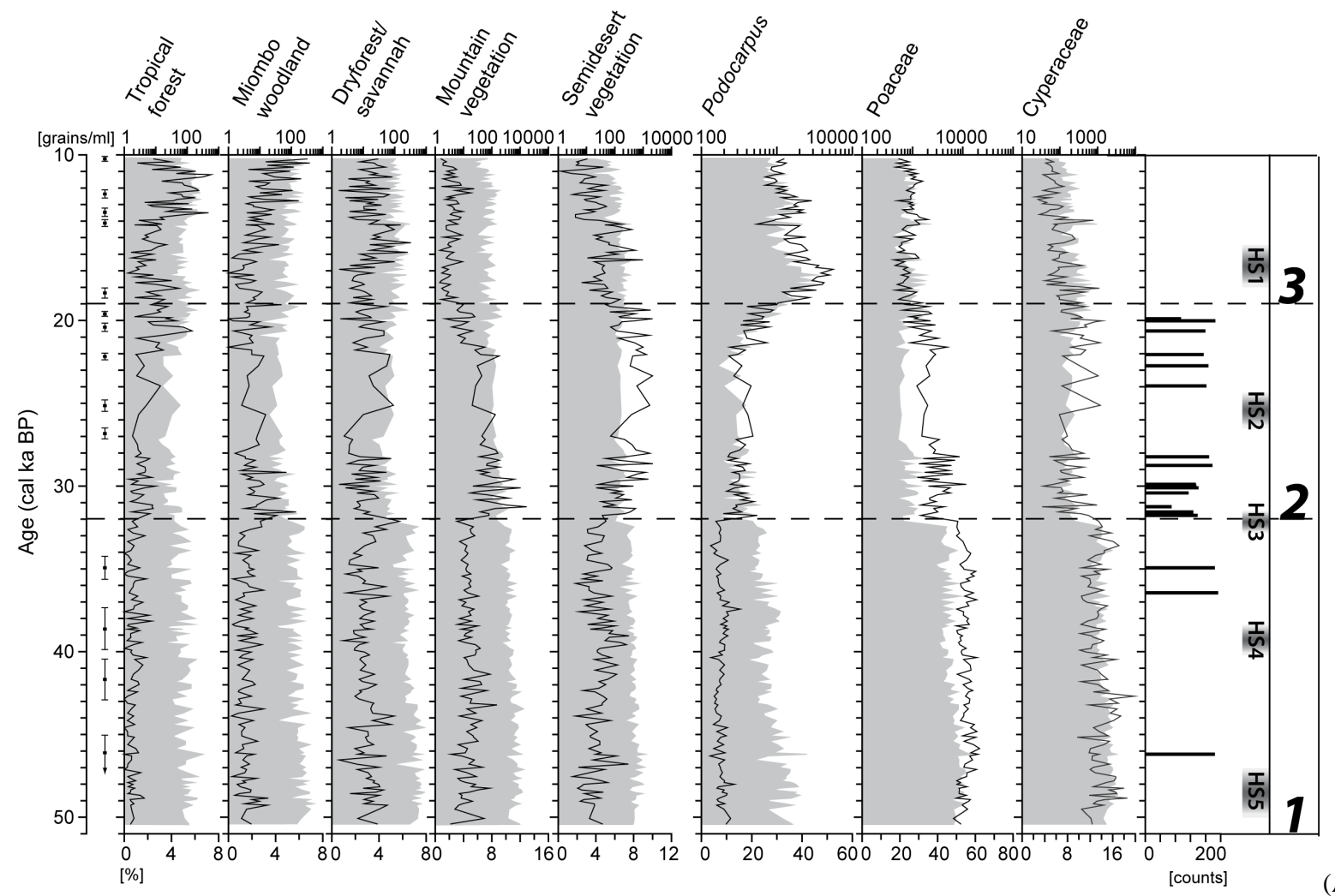

(A)

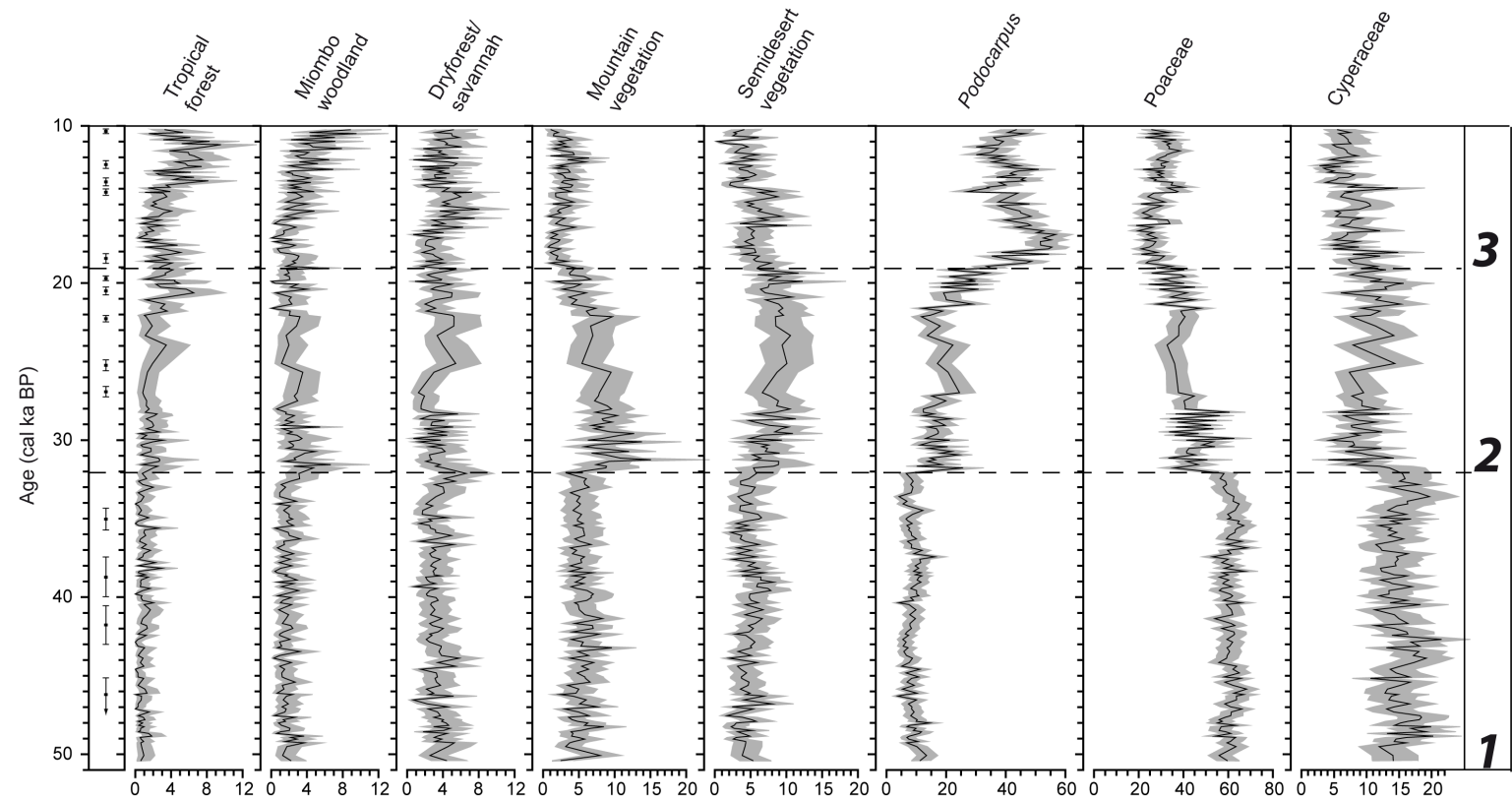

(B)

Fig. 2. (A) Pollen percentages (black) and pollen concentrations of vegetation groups and selected pollen taxa (shaded). Concentrations are given in $\log 10$ grains/ml, note different scales. Time-spans of calibrated $\mathrm{C}^{14}$ age (Kim et al., 2003; Rühlemann et al., 2004; Dupont et al., 2008) are indicated next to the time axis on the left hand side. On the right hand side, samples with less than 250 pollen grains counted are indicated. Numbers indicate Pollen-zones (PZ). PZ1 ranges from 50-32 ka BP, PZ2 from 32-19 ka BP, and PZ3 from 19-10 ka BP. Ages of Heinrich Stadials (HSs) are according to Sanchez-Goni and Harrison (2010): HS1 = 15.6-18.0 ka BP, HS2 = 24.3-26.5 ka BP, HS3 = 31.3$32.7 \mathrm{ka} \mathrm{BP}, \mathrm{HS} 4=38.3-40.2 \mathrm{ka} \mathrm{BP}$, HS5 $=47.0-50.0$. (B) Statistical precision of pollen percentages of the vegetation groups. 95\% confidence intervals have been calculated after Maher (1972) and consider the proportion of the vegetation groups within the pollen sum. Time-spans of calibrated $\mathrm{C}^{14}$ age (Kim et al., 2003; Rühlemann et al., 2004; Dupont et al., 2008) are indicated next to the time axis on the left hand side. 

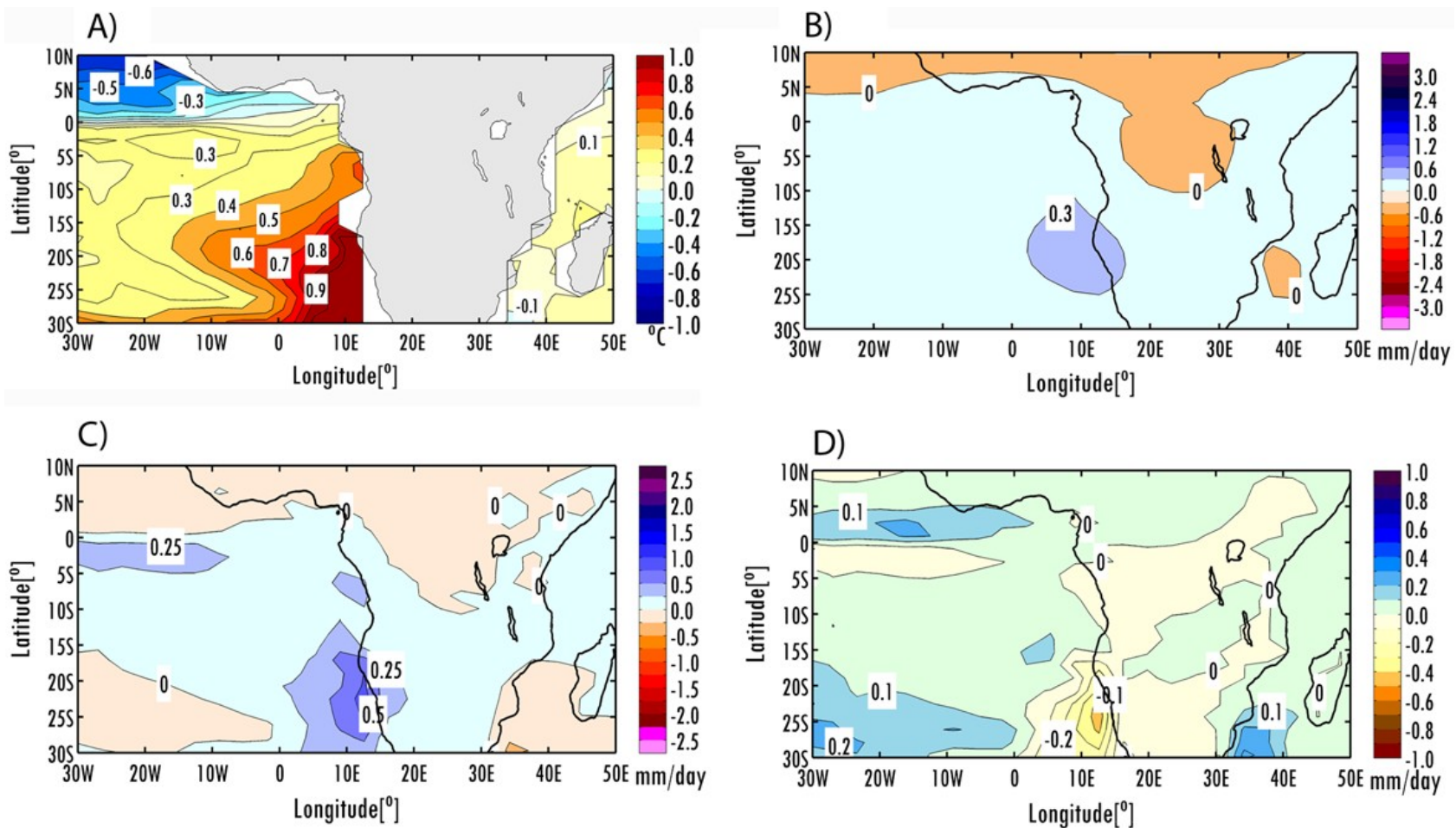

E)

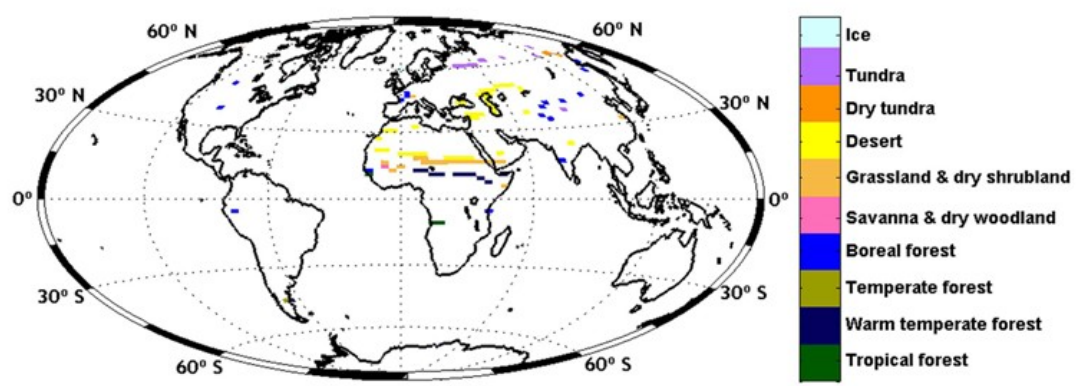

Fig. 3. Model simulations of the UVic ECSM including a dynamic vegetation component shows the anomalies between LGM and HS1 conditions. (A) Sea surface temperature in degree Celsius $\left({ }^{\circ} \mathbf{C}\right),(\mathbf{B})$ precipitation in $\mathrm{mm}$ per day, (C) evaporation in mm per day, (D) netfreshwater flux (precipitation minus evaporation) in mm per day, (E) vegetation has been grouped anomaly at HS1, vegetation into megabiomes according to Harrison and Prentice (2003). The HS1 biome of each grid cell is only plotted if it is different from the LGM biome.

Podocarpus is excluded from the group "mountain vegetation" in the pollen percentages and concentrations. It is shown separately to avoid a bias of the record, since its high pollen production rates generally result in its overrepresentation. For the same reason, values of Poaceae (grass) are not included in any vegetation group and are shown separately in the diagram.

Based on the relative abundance of pollen groups and taxa, three pollen zones (PZ1, PZ2, and PZ3) are distinguished.

Poaceae (grass) pollen dominate PZ1 (50-32 ka BP) reaching percentages up to $60 \%$. Pollen of the vegetation groups "tropical forest" (max. 2\%), "Miombo woodland" (max. $3 \%$ ), and "mountain vegetation" (max. $8.5 \%$ ), excluding the conifer Podocarpus (max. 11.5\%), show comparable low values. The concentration of Poaceae pollen is high (12000-4000 grains/ml) during PZ1, while the one of Podocarpus is low (2000-400 grains/ml). Pollen taxa summarised in the mountain and semi-desert vegetation group reach their maximum concentration at the beginning of PZ1 (mountain max. 1100 grains $/ \mathrm{ml}$; semi-desert max. 1000 grains $/ \mathrm{ml}$ ). Towards the end of PZ1 the concentration values of both groups start to decline.

Spanning the period $32-19 \mathrm{kaBP}, \mathrm{PZ2}$ is characterised by an early decline of grass pollen from about $44 \%$ to $32 \%$. Pollen percentages of sedges (Cyperaceae), which are widespread in swamps and along riversides but not restricted to them decrease during the same period to values between $4-13 \%$. The semi-desert vegetation group including taxa 
from the coastal deserts and xerophytic shrubland doubles its percentages from about $5 \%$ at the beginning of PZ2 to about $10 \%$ towards the end of the pollen zone at $19 \mathrm{kaBP}$. Pollen percentages of the group "mountain vegetation" increase significantly just at the beginning of PZ2 (32-31 ka BP) from about $4 \%$ to $10-12 \%$. However, following the maximum between $31-29 \mathrm{ka} \mathrm{BP}$, pollen percentages of this group start to decline to minimum values of $2 \%$ at about $19 \mathrm{ka} \mathrm{BP}$.

Relatively stable pollen percentages of Afromontane Podocarpus $(20 \%)$ are found during PZ2. Percentages of tropical forest reach a first maximum with $6 \%$ between 21 and $20 \mathrm{kaBP}$ and decline subsequently. However, the pollen concentrations (Fig. 2a) of Podocarpus, semi-desert, and mountain vegetation do not increase during PZ2. Indeed, all vegetation groups show at least a slight decrease in their pollen concentrations. Podocarpus concentrations are even at the lowest level (1000-200 grains/ml) during PZ2.

A strong increase of Podocarpus pollen percentages is recorded at the onset of PZ3 (19-10 ka BP), reaching its maximum representation of $52 \%$ at $\sim 17 \mathrm{kaBP}$ (see also Dupont and Behling, 2006; Dupont et al., 2008). Following this maximum, pollen percentages of Podocarpus decrease continuously to $30 \%$ at $10 \mathrm{ka} \mathrm{BP}$. Similarly, relative abundances of Poaceae, mountain, semi-desert, and dryforest/savannah pollen decline continuously until they reach minimum values at $10 \mathrm{ka}$ BP. Pollen percentages of both Miombo woodland and tropical forest reach a maximum value of $7 \%$ at $10 \mathrm{kaBP}$. A similar pattern as in the pollen percentages of Podocarpus can be observed in its concentration, with a steep increase (from 1000 to 4000 grains $/ \mathrm{ml}$ ) at the beginning of PZ3 (19-17 ka BP) followed by decreasing values down to 700 grains $/ \mathrm{ml}$ at $10 \mathrm{kaBP}$. Poaceae, mountain, and semi-desert pollen concentrations continue with their downward trend which already started in PZ2. Only the concentrations values of tropical forest (100 to 250 grains $/ \mathrm{ml}$ ) and Miombo woodland (60 to 200 grains $/ \mathrm{ml}$ ) increase slightly towards $10 \mathrm{ka} \mathrm{BP}$.

The statistical reliability of the pollen record is given in Fig. 2b. Although absolute percentages of the vegetation groups may vary within the confidence interval, the relative course of the graphs remains unaffected.

\subsection{Model results}

From the model simulations conducted with the UVic ESCM, annual-mean differences between HS1-like and LGM conditions are shown for physical parameters such as SST, precipitation, evaporation and net-surface freshwater flux (Fig. 3). All model results are taken from the last $100 \mathrm{yr}$ of each simulation and are presented as 100-yr averages.

Under HS1 conditions the SST in the South East Atlantic is between $0.5^{\circ}$ and $1.5^{\circ} \mathrm{C}$ higher compared to the LGM. Over the same region, the amount of precipitation increased by about $0.3 \mathrm{~mm}$ per day during HS1 compared to LGM conditions. Evaporation also shows higher values
(0.25-0.5 mm day ${ }^{-1}$ ) during HS1 over South West Africa and the South East Atlantic. The net-surface freshwater flux anomaly, which is the anomaly of the difference between precipitation and evaporation, is about zero in our research area.

The difference in the simulated vegetation distribution between HS1 and LGM conditions reveals a small extension of the forest biome in South West Africa during HS1 compared to the LGM (Fig. 3e).

\section{Discussion}

\subsection{The glacial vegetation development in South West Africa}

We combined the vegetation record of ODP 1078 published by Dupont and Behling (2006) and Dupont et al. (2008) for the period 30-10 ka BP with our newly obtained pollen data for the period $50-30 \mathrm{kaBP}$. This provides a more complete and distinct tropical South West African vegetation history of the last glacial and deglaciation (50-10 ka BP).

During the last glacial (here 50-19 kaBP), South West Africa was dominated by grassland and savannah vegetation indicating an open landscape likely due to drier conditions today. The low amount of arboreal taxa in the lowlands and mountain areas (Dupont and Behling, 2006; Dupont et al., 2008) supports the assumption of a reduced moisture availability. Dry and even cooler conditions during the last glacial compared to recent times are also indicated by a vegetation record from Namibia (Shi et al., 1998). The centraleast African glacial vegetation and climate history (Kashiru swamp; Bonnefille and Riolett, 1988; Bonnefille and Chalié, 2000) compares partly to the development in South West Africa presented in our study. A more open vegetation cover due to a reduction in precipitation is suggested for the period between $40 \mathrm{ka} \mathrm{BP}$ to $10 \mathrm{ka} \mathrm{BP}$ (Bonnefille and Riolett, 1988; Bonnefille and Chalié, 2000). In addition, the increasing abundance of pollen taxa representing temperate plants indicates the influence of cooler climates (Bonnefille and Riolett, 1988; Bonnefille and Chalié, 2000). However, between 50 and $40 \mathrm{ka} \mathrm{BP}$, high percentages of arboreal taxa reveal wet climate conditions similar to today (Bonnefille and Riolett, 1988). At intermediate altitude, temperate montane forest started its expansion during the LGM indicated by the increasing occurrence of Afromontane Podocarpus (Dupont et al., 2008). During deglaciation (here 19-10 ka BP), Podocarpus pollen increased significantly in our pollen record. This could represent a closure of the vegetation cover particularly on the plateau. However, this is doubtful due to the rather stable concentration of grasses, semi-desert and dryforest/savannah vegetation throughout deglaciation (Fig. 2a). Since the bisaccate pollen grains of Podocarpus are readily transported by wind, the increase could also represent an intensification of the trade winds. Although no reconstruction of trade-wind intensities from this region and/or time period 


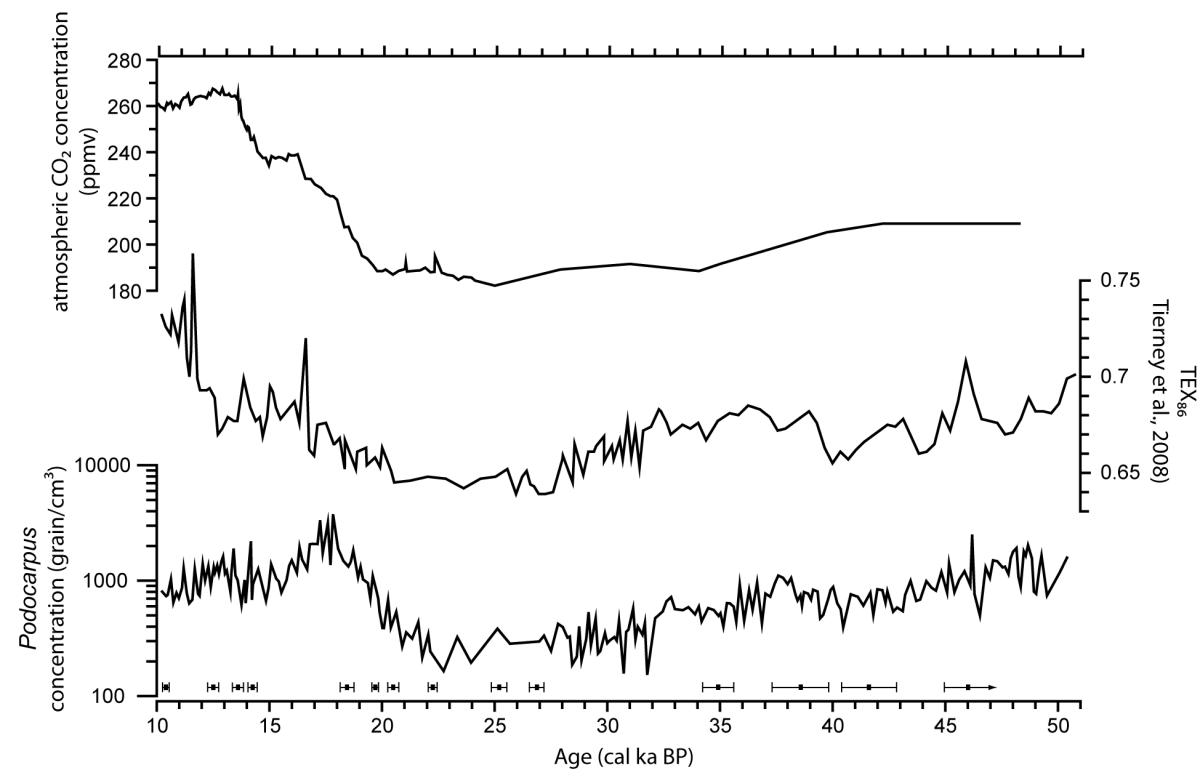

Fig. 4. Concentrations of Podocarpus (grains $/ \mathrm{cm}^{3}$ ) from ODP Site 1078 (bottom curve). Concentrations are given on log 10 scale in [grains/ml]. TEX 86 (middle) is considered to represent the lake surface temperature of Lake Tanganyika, East African Rift system (Tierney et al., 2008). Uppermost curve is a composite record of atmospheric $\mathrm{CO}_{2}$ concentration (Petit et al., 1999; Monnin et al., 2001) on the EDC3 time scale (EPICA, 2006). Timespans of calibrated $C^{14}$ age (Kim et al., 2003; Rühlemann et al., 2004; Dupont et al., 2008) are indicated on top of the time axis.

exists, an increase in wind strength appears to be a convincing mechanism.

Within dating uncertainties, there is an apparent similarity of our Podocarpus record to the east African Lake Tanganyika $\mathrm{TEX}_{86}$ record, which is considered to represent the lake's surface temperature (Fig. 4; Tierney et al., 2008). Although the amount of precipitation and the duration of the rainy season is thought to be the main limiting factor for the tropical vegetation development, the temporal evolution of Afromontane Podocarpus resembles that of tropical East African temperature (Fig. 4; Tierney et al., 2008). This suggests that in tropical high altitudes the temperature effect dominates over precipitation. As already suggested by Tierney et al. (2008) and supported by our data, it also indicates that the warming in tropical Africa occurred several thousand years before the rise in atmospheric carbon dioxide concentration.

\subsection{Abrupt climate variations in the African tropics}

The impact of millennial-scale climate fluctuations on the tropical African environment and the vegetation development has been addressed by several studies (Tierney et al., 2008; Tjallingii et al., 2008; Collins et al., 2010; Hessler et al., 2010 and references therein). In the Southern Hemisphere African tropics, vegetation changes related to HSs appear to be marked by an increase in arboreal taxa, perhaps due to an increasing moisture availability (Hessler et al., 2010). The pollen record from the Kashiru swamp in east equatorial Africa, for instance, clearly shows the impact of HSs on the vegetation with abrupt increasing percentages of arboreal taxa likely due to wetter conditions (Bonnefille and Riolett, 1988; Bonnefille and Chalié, 2000). However, Hessler et al. (2010) also indicate that the magnitude of vegetation changes associated with HSs differs from site to site. At sites where multiple HS are registered, the vegetation change is not identical. In the East African Rift system (Lake Masoko), the mountainous species Olea only increased following HS4 and HS1 (Vincens et al., 2007). As a representative of warm-temperate/mixed forest or temperate-montane forest, the increase in Olea during HSs may indicate an increase in moisture availability in the otherwise dry glacial environment (Vincens et al., 2007). In western equatorial Africa (Barombi Mbo), vegetation changes are recorded in association with HS1 and HS2 (Maley and Brenac, 1998). While Olea capensis reaches its highest abundance during HS2, grasses (Poaceae) show maximum values in relation to HS1 (Maley and Brenac, 1998).

Although several records in Southern Hemisphere Africa provide evidence for an impact of HSs on the environment, our vegetation record registered no impact of HSs in the study area. $\mathrm{Mg} / \mathrm{Ca}$-based summer sea surface temperature (SST) reconstructions of ODP Site 1078 reveal several warming episodes coinciding with HSs (Hessler et al., 2011). Thus, there is evidence for an impact of high-latitude, abrupt climate change on our study area. However, we need 
to consider that the climatic response to HSs may be simply too weak to noticeably affect the vegetation in Angola and the southern Congo Basin.

\subsection{Are millennial-scale climate changes masked in South West Africa?}

Model simulations conducted with the UVic ESCM imply that the impact of HSs on the tropical South West African vegetation may have been mitigated by counteracting mechanisms.

The simulated SST anomalies between HS1 and LGM conditions in the UVic ESCM (Fig. 3) suggest the establishment of anomalous warm conditions in the South East Atlantic during HSs. The results are consistent with an alleged warming of the South Atlantic surface waters during HSs due to a reduction or shut-down of the AMOC (the "seesaw hypothesis", Broecker, 1998) and with South East Atlantic SST reconstructions showing a warming during periods associated with HSs (Kim et al., 2002; Hessler et al., 2011). In association with the warming of the South East Atlantic, the UVic EMIC simulates an increase in the precipitation rates over the South West African continent (Fig. 3c). At the same time, there is an increase in the evaporation rates over largely the same area. Due to the opposing effects of precipitation and evaporation, the resulting net-freshwater flux nearly vanishes, except in the immediate vicinity of the Namibian upwelling region (Fig. 3d). Thus, although the hydrological cycle intensified, there was only a small change in the net moisture supply and, consequently, only a minor extension of the forest biome in South West Africa during HS1 compared to the LGM (Fig. 3e).

We therefore hypothesise that the at least partial cancellation of the increased precipitation and evaporation results in a mitigation of the HSs response in South West Africa. As a result, the climatic impact on the study area is too weak to affect the vegetation composition, as evident from our pollen record (Fig. 2a) and model experiments (Fig. 3e). However, we want to emphasise that the UVic ESCM simulations only provide one possible but plausible explanation for the absence of HSs in the vegetation record of ODP 1078.

We further want to highlight that our model results are supported by simulations conducted with a comprehensive climate model (CCSM3) (Merkel et al., 2010). The CCSM3 simulations suggest a similar partial cancellation of changes in evaporation and precipitation over South West Africa. Although the patterns and amplitudes slightly differ (not shown), they nevertheless support the findings from the UVic ESCM simulations.

\subsection{Are there other mechanisms possibly dominating the glacial South West African vegetation development?}

The counteracting mechanisms described above seem to play an important role in the climate and vegetation development in the African tropics during the last glacial. However, these may not be the only factors that affect the vegetation development in tropical environments during the last glacial. Therefore, in the following paragraph we will briefly discuss two further factors with the potential to limit the Southern Hemisphere African vegetation development.

\subsubsection{Atmospheric $\mathrm{CO}_{2}$ concentration}

The level of the atmospheric $\mathrm{CO}_{2}$ concentration plays an important role in the competitive balance of $\mathrm{C}_{4}$ and $\mathrm{C}_{3}$ plants and hence in their distribution.

The low glacial (190-200 ppmv; e.g. Petit et al., 1999) atmospheric $\mathrm{CO}_{2}$ concentration could be considered as a candidate to limit the long-term development of the tropical African vegetation substantially. Both model simulations and glasshouse experiments indicate that the concentration of atmospheric $\mathrm{CO}_{2}$ influences the global distribution of vegetation due to the different carbon dioxide fixation strategies of plants $\left(\mathrm{C}_{3}, \mathrm{C}_{4} / \mathrm{CAM}\right)$ (Ehleringer and Monson, 1993; Polley et al., 1995, 1996; Ward et al., 1999). At low $\mathrm{CO}_{2}$ concentrations, plants using the $\mathrm{C}_{3}$ photosynthetic pathway (most woody species) are less competitive than $\mathrm{C}_{4} / \mathrm{CAM}$ plants (mainly grasses and succulents), and the growth of arboreal taxa is reduced (Johnson et al., 1993; Street-Perrott et al., 1997). It is suggested that vegetation types representing the $\mathrm{C}_{4} / \mathrm{CAM}$ pathway (grassland, shrubland, savannah) were more important and widespread during the glacial compared to today (Prentice and Jolly, 2000). Model simulations conducted by Harrison and Prentice (2003) further indicate that regions which are nowadays actually or potentially covered by tropical forest were possibly occupied by more drought tolerant biomes under LGM conditions. An even larger reduction of forested areas in the tropics has been simulated if physiological effects of low atmospheric $\mathrm{CO}_{2}$ concentrations $(200 \mathrm{ppm})$ are taken into consideration (Harrison and Prentice, 2003). During deglaciation the atmospheric $\mathrm{CO}_{2}$ concentration rose, shifting the competitive balance in the direction of $\mathrm{C}_{3}$ vegetation by increasing plant productivity and water use efficiency (Pearcy and Ehleringer, 1984; Chapin et al., 1990; Johnson et al., 1993; Cowling and Sykes, 1999; Ward et al., 1999).

Applying these hypotheses to our vegetation record of Angola and the southern Congo Basin, we find that under full glacial conditions and low atmospheric $\mathrm{CO}_{2}$ concentrations, the South West African vegetation is dominated by grassland (Fig. 2a). In contrast, with increasing $\mathrm{CO}_{2}$ concentrations during deglaciation, vegetation groups representing the 
$\mathrm{C}_{3}$ pathway (tropical seasonal forest, Miombo woodland) became increasingly important (Fig. 2a).

We therefore assume that a possible explanation for the steady Angolan vegetation composition during the last glacial and the absence of HSs in the record may be the low atmospheric $\mathrm{CO}_{2}$ concentration. The potential increase in arboreal taxa during HSs may have been limited by the shift in the competitive balance towards $\mathrm{C}_{4}$ vegetation which favours the development and stability of grasslands.

\subsubsection{Monsoon circulation}

Due to reduced insolation and the presence of large ice sheets in the high latitudes of the Northern Hemisphere, the African summer monsoon circulation was weaker during the last glacial compared to today (Braconnot et al., 2000; Gasse, 2000; Janicot, 2009; Revel et al., 2010). The weakened African monsoon is another potential factor that could have dominated vegetation development in tropical Africa during the last glacial. The generally low glacial temperatures are associated with a reduction in evaporation, which in combination with a reduced monsoon circulation results in less precipitation and drier conditions (Braconnot et al., 2000). Applying these facts to our pollen record, the dry glacial conditions are reflected in the high pollen percentages of grasses (Poaceae) and the corresponding low values of groups representing tree taxa (tropical seasonal forest, Podocarpus, Miombo woodland) (Fig. 2a).

We have suggested several approaches to explain the glacial and deglacial vegetation development in South West Africa. However, the influence of factors such as (1) topographic elevation, (2) the feedback of evaporation upon ecosystems, (3) varying thresholds, and (4) speciesdependent response to variations in the prevalent $\mathrm{CO}_{2}$ concentration on the tropical vegetation development is still only partly understood and needs further investigation (e.g. Gasse et al., 2008).

\section{Conclusions}

The high-resolution vegetation record of ODP Site 1078 gives new insights into the climate and vegetation development of South West Africa between 50 and $10 \mathrm{ka}$ BP.

Throughout the last glacial, grassland and savannah vegetation dominated the pollen source area. This open vegetation type is possibly the result of reduced moisture availability and low atmospheric $\mathrm{CO}_{2}$ concentrations. During deglaciation when the monsoon strengthened and $\mathrm{CO}_{2}$ concentrations were rising, tree taxa dominated vegetation types (tropical forest, Miombo woodland) became more widespread.

The impact of abrupt climate change on the study area differs between the oceanic and terrestrial realm. While $\mathrm{Mg} / \mathrm{Ca}$ based SSTs from ODP 1078 respond to HSs (Hessler et al.,
2011), the vegetation reconstructed from the same core remains unaffected. Hence, one can assume that the climate response in South West Africa was too weak to noticeably affect the vegetation composition. However, combining our vegetation record with model results (from the UVic ESCM and CCSM3) we infer that an impact of HSs on the South West African vegetation has potentially been mitigated by counteracting mechanisms. The partial cancellation of enhanced precipitation and evaporation rates may have led to a negligible change in the moisture supply. Consequently, the resulting climatic response was possibly too weak to induce changes in the vegetation composition.

The dissimilarity between our vegetation record and the SST record of ODP 1078 (Hessler et al., 2011) regarding their response to abrupt climate variations further indicates that the vegetation development in South West Africa was decoupled from variations in the SST, and no direct land-sea correlation existed in the study area during HSs.

We further assume that the low glacial atmospheric $\mathrm{CO}_{2}$ concentration may have limited the vegetation response to HSs by favouring the development of grassland over the expansion of forest.

We particularly want to highlight that the results presented here show that the HS response in Southern Hemisphere Africa neither equals nor mirrors the northern African response to abrupt climate variations such as HSs.

\section{Supplementary material related to this article is available online at: http://www.clim-past.net/8/841/2012/ cp-8-841-2012-supplement.pdf.}

Acknowledgements. The authors want to thank Anngret Krandick for preparing a substantial part of the samples.

We thank the Ocean Drilling Program for providing samples. This study was funded by the Deutsche Forschungsgemeinschaft (grant DU221/3) and by the Deutsche Forschungsgemeinschaft as part of the DFG-Research Center/Cluster of Excellence "The Ocean in the Earth System". Data are available in Pangaea, www.pangaea.de.

Edited by: M. Claussen

\section{References}

Alley, R. B., Clark, P. U., Keigwin, L. D., and Webb, R. S.: Making sense of millennial scale climate change, in: Mechanisms of Global Climate Change at Millennial Time Scales, edited by: Clark, P. U.,Webb, R. S., and Keigwin, L. D., Geophysical Monograph Vol. 112, American Geophysical Union, Washington, 385-394, 1999.

Barker, S., Diz, P., Vautravers, M. J., Pike, J., Knorr, G., Hall, I. R., and Broecker, W. S.: Interhemispheric Atlantic seesaw response during the last deglaciation, Nature, 457, 1097-1102, 2009.

Bonnefille, R. and Riollet, G.: Pollens des savanes d'Afrique orientale, CNRS Editions, Paris, 140 pp., 1980. 
Bonnefille, R. and Riollet, G.: The Kashiru pollen sequence (Burundi) palaeoclimatic implications for the last 40,000 yr B.P. in tropical Africa, Quaternary Res., 30, 19-35, 1988.

Bonnefille, R. and Chalié, F.: Pollen-inferred precipitation timeseries from equatorial mountains, Africa, the last $40 \mathrm{kyr} \mathrm{BP}$, Global Planet. Change, 26, 25-50, 2000.

Braconnot, P., Joussaume, S., de Noblet, N., and Ramstein, G.: Mid-Holocene and Last Glacial Maximum African monsoon changes as simulated within the Paleoclimate Modelling Intercomparison Project, Global Planet. Change, 26, 51-66, 2000.

Broecker, W. S.: Massive iceberg discharges as triggers for global climate change, Nature, 372, 421-424, 1994.

Broecker, W. S.: Glacial Climate in the Tropics, Science, 272, 1902-1904, 1996.

Broecker, W. S.: Paleocean circulation during the last deglaciation: A bipolar seesaw?, Paleoceanography, 13, 119-121, 1998.

Butzin, M., Prange, M., and Lohmann, G.: Radiocarbon simulations for the glacial ocean: The effects of wind stress, Southern Ocean sea ice and Heinrich events, Earth Planet. Sc. Lett., 235, 45-61, 2005.

Chapin, F. S., Schulze, E. D., and Mooney, H. A.: The ecology and economics of carbon storage in plants, Annu. Rev. Ecol. Syst., 21, 423-447, 1990.

Claussen, M., Mysak, L. A., Weaver, A. J., Crucifix, M., Fichefet, T., Loutre, M.-F., Weber, S. L., Alcamo, J., Alexeev, V. A., Berger, A., Calov, R., Ganopolski, A., Goosse, H., Lohman, G., Lunkeit, F, Mokhov, I. I., Petoukhov, V., Stone, P., and Wang, Zh.: Earth System Models of Intermediate Complexity: Closing the Gap in the Spectrum of Climate System Models, Clim. Dynam., 18, 579-586, 2002.

Collins, J. A., Schefusz, E., Heslop, D., Mulitza, S., Prange, M., Zabel, M., Tjallingii, R., Dokken, T. M., Huang, E., Mackensen, A., Schulz, M., Tian, J., Zarriess, M., and Wefer, G.: Interhemispheric symmetry of the tropical African rainbelt over the past 23,000 years, Nat. Geosci., 4, 42-45, 2010.

Cowling, S. A. and Sykes, M. T.: Physiological Significance of Low Atmospheric $\mathrm{CO}_{2}$ for Plant-Climate Interactions, Quaternary Res., 52, 237-242, 1999.

Cox, P. M.: Description of the TRIFFID dynamic global vegetation model Hadley Center technical note 24, 1-17, 2001.

Cox, P. M., Betts, R. A., Bunton, C. B., Essery, R. L. H., Rowntree, P. R., and Smith, J.: The impact of new land surface physics on the GCM simulation of climate and climate sensitivity, Clim. Dynam., 15, 183-203, 1999.

Dupont, L.: Orbital scale vegetation change in Africa, Quaternary Sci. Rev., 30, 3589-3602, 2011.

Dupont, L. M. and Behling, H.: Land-sea linkages during deglaciation: High-resolution records from the eastern Atlantic off the coast of Nambia and Angola, Quatern. Int., 148, 19-28, 2006.

Dupont, L. M. and Wyputta, U.: Reconstructing pathways of aeolian pollen transport to the marine sediments along the coastline of SW Africa, Quaternary Sci. Rev., 22, 157-174, 2003.

Dupont, L. M., Behling, H., and Kim, J.-H.: Thirty thousand years of vegetation development and climate change in Angola (Ocean Drilling Program Site 1078), Clim. Past, 4, 107-124, doi:10.5194/cp-4-107-2008, 2008.

Dupont, L. M., Schlütz, F., Teboh Ewah, C., Jennerjahn, T. C., Paul, A., and Behling, H.: Two-step vegetation response to enhanced precipitation in Northeast Brazil during Heinrich event 1, Global
Change Biol., 16, 1647-1660, 2010.

Ehleringer, J. R. and Monson, R. K.: Evolutionary and Ecological Aspects of Photosynthetic Pathway Variations, Annu. Rev. Ecol. Syst., 24, 411-439, 1993.

EPICA Community Members: One-to-one coupling of glacial climate variability in Greenland and Antarctica, Nature, 444, 195198, 2006.

Faegri, K., and Iversen, J.: Textbook of pollen analysis, 4th Edn., edited by: Faegri, K., Kaland, P. E., Krzywinski, K., and Wiley, K., Blackburn, New York, 1989.

Fairbanks, R. G., Mortlock, R. A., Chiu, T.-C., Cao, L., Kaplan, A., Guilderson, T. P., Fairbanks, T. W., and Bloom, A. L.: Marine Radiocarbon Calibration Curve Spanning 10,000 to 50,000 Years B.P., Based on Paired $\mathrm{Th}^{230} / \mathrm{U}^{234} / \mathrm{U}^{238}$ and $\mathrm{C}^{14}$ Dates on Pristine Corals, Quaternary Sci. Rev., 24, 1781-1796, 2005.

Franke, J., Paul, A., and Schulz, M.: Modeling variations of marine reservoir ages during the last 45000 years, Clim. Past, 4, 125136, doi:10.5194/cp-4-125-2008, 2008.

Gasse, F.: Hydrological changes in the African tropics since the Last Glacial Maximum, Quaternary Sci. Rev., 19, 189-211, 2000.

Gasse, F., Chalié, F., Vincens, A., Williams, M. A. J., and Williamson, D.: Climatic patterns in equatorial and southern Africa from 30,000 to 10,000 years ago reconstructed from terrestrial and near-shore proxy data, Quaternary Sci. Rev., 27, 2316-2340, 2008.

González, C. and Dupont, L.: Tropical salt marsh succession as sealevel indicator during Heinrich events, Quaternary Sci. Rev., 28, 939-946, 2009.

González, C., Dupont, L. M., Behling, H., and Wefer, G.: Neotropical vegetation response to rapid climate changes during the last glacial period: Palynological evidence from the Cariaco Basin, Quaternary Res., 69, 217-230, 2008.

Handiani, D., Paul, A., and Dupont, L.: Tropical climate and vegetation changes during Heinrich Event 1: a model-data comparison, Clim. Past, 8, 37-57, doi:10.5194/cp-8-37-2012, 2012.

Harrison, S. P. and Prentice, C. I.: Climate and $\mathrm{CO}_{2}$ controls on global vegetation distribution at the last glacial maximum: analysis based on palaeovegetation data, biome modeling and palaeoclimate simulations, Global Change Biol., 9, 983-1004, 2003.

Heinrich, H.: Origin and consequences of cyclic ice rafting in the Northeast Atlantic Ocean during the past 130,000 years, Quaternary Res., 29, 142-152, 1988.

Hessler, I., Dupont, L., Bonnefille, R., Behling, H., González, C., Helmens, K. F., Hooghiemstra, H., Lebamba, J., Ledru, M.-P., Lézine, A.-M., Maley, J., Marret, F., and Vincens, A.: Millennial-scale changes in vegetation records from tropical Africa and South America during the last glacial, Quaternary Sci. Rev., 29, 2882-2899, 2010.

Hessler, I., Steinke, S., Groeneveld, J., Dupont, L., and Wefer, G.: Impact of abrupt climate change in the tropical southeast Atlantic during Marine Isotope Stage (MIS) 3, Paleoceanography, 26, PA4209, doi:10.1029/2011pa002118, 2011.

Hooghiemstra, H., Lezine, A.-M., Leroy, S. A. G., Dupont, L., and Marret, F.: Late Quaternary palynology in marine sediments: A synthesis of the understanding of pollen distribution patterns in the NW African setting, Quatern. Int., 148, 29-44, 2006. 
Hostetler, S. W., Clark, P. U., Bartlein, P. J., Mix, A. C., and Pisias, N. J.: Atmospheric transmission of North Atlantic Heinrich events, J. Geophys. Res., 104, 3947-3952, 1999.

Hughen, K. A., Baillie, M. G. L., Bard, E., Beck, J. W., Bertrand, C. J. H., Blackwell, P. G., Buck, C. E., Burr, G. S., Cutler, K. B., Damon, P. E., Edwards, R. L., Fairbanks, R. G., Friedrich, M., Guilderson, T. P., Kromer, B., McCormac, G., Manning, S., Bronk Ramsey, C., Reimer, P. J., Reimer, R. W., Remmele, S., Southon, J. R., Stuiver, M., Talamo, S., Taylor, F. W., van der Plicht, J., and Weyhenmeyer, C. E.: MARINE04 Marine Radiocarbon Age Calibration, 0-26 cal kyr BP, Radiocarbon, 46, 10591086, 2004.

Janicot, S.: A comparison of Indian and African monsoon variability at different times scales, Comptes Rendus Geoscience, 341, 575-590, 2009.

Johnson, H. B., Polley, H. W., and Mayeux, H. S.: Increasing $\mathrm{CO}_{2}$ and plant-plant interactions: effects on natural vegetation, Vegetatio, 104/105, 157-170, 1993.

Kim, J.-H., Schneider, R. R., Müller, P. J., and Wefer, G.: Interhemispheric comparison of deglacial sea-surface temperature patterns in Atlantic eastern boundary currents, Earth Planet. Sc. Lett., 194, 383-393, 2002.

Kim, J.-H., Schneider, R. R., Mulitza, S., and Müller, P. J.: Reconstruction of SE trade-wind intensity based on sea-surface temperature gradients in the Southeast Atlantic over the last $25 \mathrm{kyr}$, Geophys. Res. Lett., 30, 2144-2147, 2003.

Lee, S.-Y., Chiang, J. C. H., Matsumoto, K., and Tokos, K. S.: Southern Ocean wind response to North Atlantic cooling and the rise in atmospheric $\mathrm{CO}_{2}$ : Modeling perspective and paleoceanographic implications, Paleoceanography, 26, PA1214, doi:10.1029/2010pa002004, 2011.

Leroux, M.: Le climat de L'Afrique tropicale (Texte and atlas), Champion, Paris, France, 1983.

Maher, L. J.: Nomograms for Computing 0.95 Confidence Limits of Pollen Data, Rev. Palaeobot. Palynol., 13, 85-93, 1972.

Maley, J.: Contributions à l'étude du bassin tchadien, Atlas de pollens du Tchad, Bulletin du Jardin botanique national de Belgique, 40, 29-48, 1970.

Maley, J. and Brenac, P.: Vegetation dynamics, palaeoenvironments and climatic changes in the forests of western Cameroon during the last 28,000 years B.P., Rev. Palaeobot. Palynol.., 99, 157$187,1998$.

Merkel, U., Prange, M., and Schulz, M.: ENSO variability and teleconnections during glacial climates, Quaternary Sci. Rev., 29, 86-100, 2010.

Monnin, E., Indermühle, A., Dällenbach, A., Flückiger, J., Stauffer, B., Stocker, T. F., Raynaud, D., and Barnola, J.-M.: Atmospheric $\mathrm{CO}_{2}$ Concentrations over the Last Glacial Termination, Science, 291, 112-114, 2001.

Mulitza, S., Prange, M., Stuut, J.-B., Zabel, M., von Dobeneck, T., Itambi, A. C., Nizou, J., Schulz, M., and Wefer, G.: Sahel megadroughts triggered by glacial slowdowns of Atlantic meridional overturning, Paleoceangraphy, 23, 1-11, 2008.

Nicholson, S. E.: The nature of rainfall variability over Africa on time scales of decades to millenia, Global Planet. Change, 26, 137-158, 2000.

Nicholson, S. E. and Entekhabi, D.: Rainfall Variability in Equatorial and Southern Africa: Relationships with Sea Surface Temperatures along the Southwestern Coast of Africa, J. Clim. Appl.
Meteorol., 26, 561-578, 1987.

Pearcy, R. W. and Eherlinger, J.: Comparative ecophysiology of $\mathrm{C}_{3}$ and $\mathrm{C}_{4}$ plants, Plant Cell Environ., 7, 1-13, 1984.

Petit, J. R., Jouzel, J., Raynaud, D., Barkov, N. I., Barnola, J.-M., Basile, I., Bender, M., Chappellaz, J., Davis, M., Delaygue, G., Delmotte, M., Kotlyakov, V. M., Legrand, M., Lipenkov, V. Y., Lorius, C., Pépin, L., Ritz, C., Saltzman, E., and Stievenard, M.: Climate and atmospheric history of the past 420,000 years from the Vostok ice core, Antarctica, Nature, 399, 429-436, 1999.

Polley, H. W., Johnson, H. B., and Mayeux, H. S.: Nitrogen and water requirements of $\mathrm{C}_{3}$ plants grown at glacial to present carbon dioxide concentrations, Funct. Ecol., 9, 86-96, 1995.

Polley, H. W., Johnson, H. B., Mayeux, H. S., Brown, D. A., and White, J. W. C.: Leaf and plant water use effeciency of $\mathrm{C}_{4}$ species grown at glacial to elevated $\mathrm{CO}_{2}$ concentrations, Int. J. Plant Sci., 157, 164-170, 1996.

Prentice, I. C. and Jolly, D.: BIOME 6000 participants, MidHolocene and glacial-maximum vegetation geography of the northern continents and Africa, J. Biogeogr., 27, 507-519, 2000.

Revel, M., Ducassou, E., Grousset, F. E., Bernasconi, S. M., Migeon, S., Revillon, S., Mascle, J., Murat, A., Zaragosi, S., and Bosch, D.: 100,000 Years of African monsoon variability recorded in sediments of the Nile margin, Quaternary Sci. Rev., 29, 1342-1362, 2010.

Rühlemann, C., Mulitza, S., Lohmann, G., Paul, A., Prange, M., and Wefer, G.: Intermediate depth warming in the tropical Atlantic related to weakened thermohaline circulation: Combining paleoclimate and modeling results for the last deglaciation, Paleoceanography, 19, PA1025, doi:10.1029/2003PA000948, 2004.

Sanchez Goñi, M. F. and Harrison, S .P., Millennial-scale climate variability and vegetation changes during the Last Glacial: Concepts and terminology, Quaternary Sci. Rev., 29, 2823-2827, 2010.

Shannon, L. V. and Nelson, G.: The Benguela: Large Scale Features and Processes and System Variability, in: The South Atlantik: Present and Past Circulation, edited by: Wefer, G., Berger, W. H., Siedler, G., and Webb, D. J., Springer-Verlag, Berlin, Heidelberg, 163-210, 1996.

Shannon, L. V., Agenbag J. J., and Buys, M. E. L.: Large- and mesoscale features of the Angola-Benguela Front, South Afr. J. Mar. Sci., 5, 11-34, 1987.

Shi, N., Dupont, L. M., Beug, H.-J., and Schneider, R.: Vegetation and climate changes during the last 21000 years in S.W. Africa based on a marine pollen record, Veg. Hist. Archaeobot., 7, 127 $140,1998$.

Sowunmi, M. A.: Pollen grains of Nigerian plants, Grana, 13, 145186, 1973.

Sowunmi, M. A.: Pollen of Nigerian plants 2. Woody species, Grana, 34, 39-44, 1995.

Stockmarr, J.: Tablets with spores used in absolute pollen analysis, Pollen Spores, 13, 615-621, 1971.

Stouffer, R., Yin, J., Gregory, J., Dixon, K., Spelman, M., Hurlin, W., Weaver, A., Eby, M., Flato, G., Hasumi, H., Hu, A., Jungclaus, J., Kamenkovich, I., Levermann, A., Montoya, M., Murakami, S., Nawrath, S., Oka, A., Peltier, W., Robitaille, D., Sokolov, A., Vettoretti, G., and Weber, S.: Investigating the causes of the response of the thermohaline circulation to past and future climate changes, J. Climate, 19, 1365-1387, 2006. 
Stramma, L. and Peterson, R. G.: Geostrophic Transport in the Benguela Current Region, J. Phys. Oceanogr., 19, 1440-1448, 1989.

Street-Perrott, F. A., Huang, Y., Perrott, R. A., Eglinton, G., Barker, P., Khelifa, L. B., Harkness, D. D., and Olago, D. O.: Impact of Lower Atmospheric Carbon Dioxid on Tropical Mountain Ecosystems, Science, 278, 1422-1426, 1997.

Stuiver, M., Reimer, P. J., Bard, E., Beck, W., Burr, G. S., Hughen, K. A., Kromer, B., McCormac, G., van der Pflicht, J., and Spurk, M.: INTCAL98 radiocarbon age calibration, 24,000-0 cal BP, Radiocarbon, 40, 1041-1083, 1998.

Sultan, B. and Janicot, S.: The West African Monsoon Dynamics, Part 2: The "Preonset" and "Onset" of the Summer Monsoon, J. Climate, 16, 3407-3427, 2003.

Tierney, J. E., Russell, J. M., Huang, Y., Damste, J. S. S., Hopmans, E. C., and Cohen, A. S.: Northern Hemisphere Controls on Tropical Southeast African Climate During the Past 60,000 Years, Science, 322, 252-255, 2008.

Tjallingii, R., Claussen, M., Stuut, J.-B. W., Fohlmeister, J., Jahn, A., Bickert, T., Lamy, F., and Röhl, U.: Coherent high- and lowlatitude control of the northwest African hydrological balance, Nat. Geosci., 1, 670-675, 2008.

Vellinga, M. and Wood, R. A.: Global Climatic Impacts of a Collapse of the Atlantic Thermohaline Circulation, Climatic Change, 54, 251-267, 2002.
Vincens, A., Garcin, Y., and Buchet, G.: Influence of rainfall seasonality on African lowland vegetation during the late Quaternary: pollen evidence from Lake Masoko, Tanzania, J. Biogeogr., 24, 1274-1288, 2007.

Ward, J. K., Tissue, D. T., Thomas, R. B., and Strain, B. R.: Comparative responses of model $\mathrm{C}_{3}$ and $\mathrm{C}_{4}$ plants to drought in low and elevated $\mathrm{CO}_{2}$, Global Change Biol., 5, 857-867, 1999.

Weaver, A. J., Eby, M., Wiebe, E. C., Bitz, C. M., Duffy, P. B., Ewen, T. L., Fanning, A. F., Holland, M. M., MacFadyen, A., Matthews, H. D., Meissner, K. J., Saenko, O., Schmittner, A., Wang, H., and Yoshimori, M.: The UVic earth system climate model: Model description, climatology, and applications to past, present and future climates, Atmos.-Ocean, 39, 361-428, 2001.

Wefer, G., Berger, W. H., Richter, C., and Scientific Shipboard Party: Proceedings of the Ocean Drilling Program, Initial. Reports, 175, Ocean Drilling Program, College Station, TX 1998.

White, F.: The Vegetation of Africa. Natural Rescourses Research, UNESCO, 353 mapsp, p. 356, 1983.

Ybert, J. P.: Altas des pollens de Côte d'Ivoire, Initiations Documentation Technique 40, ORSTOM, Paris, 40 pp., 1979.

Zhang, R. and Delworth, T. L.: Simulated tropical response to a substantial weakening of the Atlantic Thermohaline Circulation, J. Climate, 18, 1853-1860, 2005. 